\title{
A Risk Based Approach to Evaluating the Impacts of Zayanderood Drought on Sustainable Development Indicators of Riverside Urban in Isfahan-Iran
}

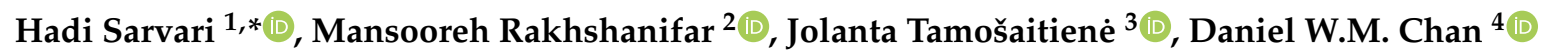 \\ and Michael Beer 5 \\ 1 Department of Civil Engineering, Isfahan (Khorasgan) Branch, Islamic Azad University, \\ Isfahan 81595-39998, Iran \\ 2 Faculty of Civil Engineering, Universiti Teknologi Malaysia, Johor, Skudai 81310, Malaysia; \\ mansooreh.rakhshanifar@gmail.com \\ 3 Faculty of Civil Engineering, Vilnius Gediminas Technical University, Sauletekio al. 11, \\ LT-10223 Vilnius, Lithuania; jolanta.tamosaitiene@vgtu.lt \\ 4 Department of Building and Real Estate, The Hong Kong Polytechnic University, Hung Hom, Kowloon, \\ Hong Kong, China; daniel.w.m.chan@polyu.edu.hk \\ 5 Institute for Risk and Reliability, Leibniz Universität Hannover, Callinstrasse 34, 30167 Hannover, Germany; \\ beer@irz.uni-hannover.de \\ * Correspondence: h.sarvari@khuisf.ac.ir; Tel.: +98-901-727-7879
}

Received: 1 October 2019; Accepted: 20 November 2019; Published: 29 November 2019

check for updates

\begin{abstract}
In recent years, the Zayanderood River in Isfahan-Iran has been encountered by hydrological imbalance and drought. Literature review shows that long-term climate change, drought, and disruption of the river's water supply has led to depletion of underground aquifers and, consequently, gradual subsidence of the river and serious damage to old buildings and structures along the riverbank. This fact would be followed up by adverse environmental, social, and economic effect that could threaten the sustainable development of urban space. Therefore, it is necessary to use efficient risk identification and assessment approaches toward a more effective risk management. The goal of this study is to identify and prioritize the risks of river drought with regards to all three sustainable development areas including environmental, social, and economic. The research methodology was a mixed field method that included a set of questionnaires and interviews. To evaluate collected data, the analytic network process (ANP) method was used. Eighteen important risks were identified. Based on the results, decrease in the groundwater level, climate change, and gradual soil degradation were ranked first, second, and third, respectively. As this study examined the impacts of river drought on all three areas of sustainable development simultaneously and comprehensively, it is expected that the results will fill the existing theoretical and practical gap affecting improvements in assessment and management of sustainable development risks.
\end{abstract}

Keywords: Drought; Sustainable development; Urban space; Risk assessment; Isfahan; Iran

\section{Introduction}

The Zayanderood River, which is a vital vein of fertility in the city of Isfahan, has experienced drought and hydrological imbalances for the last two decades [1]. The Zayanderood is the biggest river in the central desert of Iran. Zayanderood plays an important role in supplying drinking, industrial, and agricultural water resources in Isfahan province. Unfortunately, the river's movement has been broken due to hydrological drought that has occurred in the last few years. 
As water is one of the most pressing human needs, drought and water scarcity are one of the biggest challenges facing the development of the country in the present and future [2]. Therefore, Zayanderood drought is one of the most important environmental, social, and economic crises in Iran in recent years. Continuous trend of the drought will increase the intensity of the ecological changes in Isfahan, endangering its life and future.

Development in the vicinity of the river is dependent on the riverbed and, in fact, has an interplay as changes and instability in any of them systematically affect the other one. The severe decline in groundwater resources, social tensions, drying up of the Zayanderood River, and Gavkhooni wetlands are the major consequences of drought in Isfahan, which are a serious threat to sustainable development of Isfahan [3]. Although apparently Zayanderood drought has nothing to do with the construction, it should be noted that the long-term disruption of water in Zayanderood has been associated with a decrease in the level of underground aquifers and a gradual subsidence of the earth which can play a major role in damaging the structures and folds of existing buildings, especially historical sites [4]. On the other hand, considerations on the possibility of gradual subsidence due to the drought is necessary in the calculation of new buildings, and construction engineers should pay particular attention to the design and implementation of buildings (in the context of structures or installations). All of these can be a restraining factor to achieve the sustainable development goals of Isfahan, which has been intensely focused by local authorities and managers in recent years.

The occurrence of any of the environmental, social, and economic consequences (as the three main areas of sustainable development) of the emerging crisis certainly follow a series of long, medium, and short-term causal relationships. In principle, the continuation of the Zayanderood drought process has such a negative effect on environmental, social and economic dimensions that can therefore be critical to the sustainability of Isfahan [3]. Among previous research work, there is no comprehensive research that simultaneously examined the effects of the river drought on all three areas of sustainable development. Therefore, the aim of this study was to prioritize effects of the drought on sustainable development indicators in the buildings and urban space located in the vicinity of the river (as identified risks). In order to achieve this goal, this study organized to thoroughly examine all three environmental, social, and economic aspects of sustainable development using the risk assessment model and Analytical Network Process (ANP) approach (as a multi-criteria decision-making method) to control the situation, better management and improvements by identification, prioritization, and assessment of the risks. An in-depth review of previous research showed that relatively less research has investigated the effects of the drought on all three sustainable development indicators $[5,6]$. Throughout the literature, with careful study, it can be seen that only one or two aspects of sustainable development have been considered in a single study, and none of these researches have been taken into account in all three aspects. This is the latest gap between previous studies. The distinction between the economy, environment, and community reflected by the sustainability indicators have been studied in the literature $[7,8]$, although the relative importance of the three dimensions on assessment of sustainable development needs wider scientific agreement and standardization [9]. There is an indication that the environmental objectives and indicators of sustainable development are more coherent than the social ones [10]. Also, most of the literature of sustainable development deal with either socio-economic or socio-environmental development factors of the nations [9]. In addition, no research that represents a comprehensive approach of experts (experienced in the area such as geotechnical engineering, civil engineering, architecture, water resource engineering, economists and other related specialties) has been found. In fact, this attempt has been made to bridge the gap between previous studies.

\section{Literature Review}

Extensive study on the Zayanderood River drought has indicated that against the excessive concerns on the issue of the Zayanderood drought crisis management and due to disregarding various dimensions and consequences of this crisis, adequate control measures are not in place. Therefore, it is 
necessary to carry out a specific study on the different dimensions of the Zayanderood drought and its effective risk management. As such, this study categorized the investigation into two major groups: the first group examined the main roots and causes that have led to the Zayanderood drought, while the second group considered the consequences of this drought.

\subsection{Drought Causes}

Disregarding the effects of climate change has a negative impact on sustainable development [11]. In an article on the effects of climate change on the flow of the Zayanderood River in Esfahan, Bowani and Murid stated that the results showed an overall decrease in precipitation and an increase in temperature [12]. Research performed by Moradi and Nozari also investigated climate change as one of the causes of Zayanderood water scarcity and drought [13]. On the other hand, it has been claimed that although climate change has no effects on temperature and rainfall in Isfahan, the relative humidity decreased, the number of dry months increased, and, in fact, the climate has since become drier [14].

Globally, climate change has raised serious concern for many researchers. In this approach, the research developed by Rajkovich and Okour highlighted the importance of planning for future building stock by considering rapid global climate change instead of sole reliance on historical data [15]. Resilience sustainable development approach with regards to climate change is globally attractive [16].

\subsection{Drought Effects}

The effects of drought may influence environmental, social, and economic indicators. Environmental impacts result in damage to air and water quality, degradation of landscape quality, and soil erosion. Some effects are only short term, but other environmental impacts can create long-lasting or even permanent effects in many different aspects.

Climate change may be due to regional climate change and geology. The Mediterranean region is affected by climate change, which is mainly reflected in its effects on water supplies and lack of flow. In Lebanon, the so-called "hydrological drought" caused a significant decline in water resources (surface and groundwater) by 23 to 29 percent over the past four decades [17]. Hydrological droughts reduce the water level of lakes and water reservoirs, reduce the quality of water, reduce the level of supply for electricity generation, and result in financial and social damages [18]. Prediction and timely alerts may result in application of the suitable water resources management [19].

In fact, changes in the annual natural precipitation table indicate that the decrease in groundwater level is due to the interaction of precipitation and river flow, which has reduced the natural productivity of groundwater [20]. Evaluation of the relationship between drought and its impact on surface and groundwater resources shows that this relationship is significant with high correlation [21]. Variations of flow in the study area have contributed significantly to the decline in groundwater levels. Therefore, considering the decrease or unchanged groundwater discharge in recent years, it can be concluded that the reduction of water flow in the Zayanderood has been significantly influenced by changes in groundwater level, and in the areas with the greatest reduction in the water flow, the reduction in groundwater level in areas near the river is more severe than in other areas [22].

The results of the research by Mirasi et al. suggest that a $23 \mathrm{~m}$ drop in groundwater level is one of the major causes of soil subsidence [23]. The results of the study by Diaz et al. indicate that buildings located in subdued areas are vulnerable, which can reduce the livability and, in some cases, endanger safety of the structures erected in the area. Any inhomogeneity can intensify the consequences of subsidence and cause serious damage to the building. In addition, soil inhomogeneities can worsen damage due to changes in the thickness or properties of the following non-reforming layers [24]. Reducing soil moisture results in a decrease in groundwater levels [25]. On the other hand, the effect of changes in groundwater level and soil moisture on the structural stability of buildings and ground water systems and soil moisture conditions is expected as a result of environmental changes. Most of the damage reported is to buildings where groundwater depletion occurs at shallow foundations. However, deep piles can also be affected [26]. Simulation of the effect of the climatic changes caused 
by the increase in greenhouse gases on the Zayanderood flow has been done in other research in which a decrease of flow in April and May was reported, of which a decrease in precipitation in these months and an increase in temperature are the reasons [27].

There is also a social impact during periods of drought [28]. According to the results of Maleki and Ahmad Pour's research, during the period under study, it has been shown that drought has had negative effects on the number of annual visits to Isfahan [29]. Citizens' collective memories of the river and its landscape are changing, and the identity of the river and the city is under serious threat [30]. Zayanderood drought has also had economic, social, and psychological impacts on Isfahan businesses, and has also had environmental impacts [31]. Zayanderood drought has an increasing impact on reducing tourism in Isfahan as well [2]. In recent years, the crisis caused by microfluid in Isfahan province and city has been one of the most tangible, natural disasters affecting the daily life of citizens, and also the economy of the area. If the river drying process continues and the wetland water right there in the near future, Gavkhuni wetland could also become a major source of microfluidic production in Isfahan and even other provinces [32]. Incidence and the spreading of disease are among other consequences created by the drought. The case becomes more critical due to the effects of infected society on the environment, as pointed by Antronico et al [33].

The economic impact occurs in sectors that depend on water resources, in addition to sudden damage to wind erosion. Climate change, in general, (due to the need to provide cooling at the houses during the hot season) imposes an excessive load on the electricity supply [34]. Climate change affects many aspects of building performance, as many parts of the existing and future buildings are likely to be affected [35].

Hydrological drought and drying out of the river base, and climate change in the Zayanderood and its impact on sustainable development indices has been addressed in relatively large studies (e.g., $[1,3,12-14,22,27,29-32])$. Only one or ultimately two indicators of sustainable development in each research have been addressed so far. None of them have addressed this issue comprehensively with all three sustainability indicators. Cramer et al. emphasized the importance of considering a comprehensive and coherent assessment of risks affecting sustainable development as well [5]. Figure 1 was developed by the authors throughout extensive study on the literature review. It shows the causes and effects of drought in the Zayanderood, which are categorized into three groups (social, environmental and economic related causes). The provided causes and effects are explicitly expanded by the authors and analyzed quantitatively, as explained in Section 4.1.

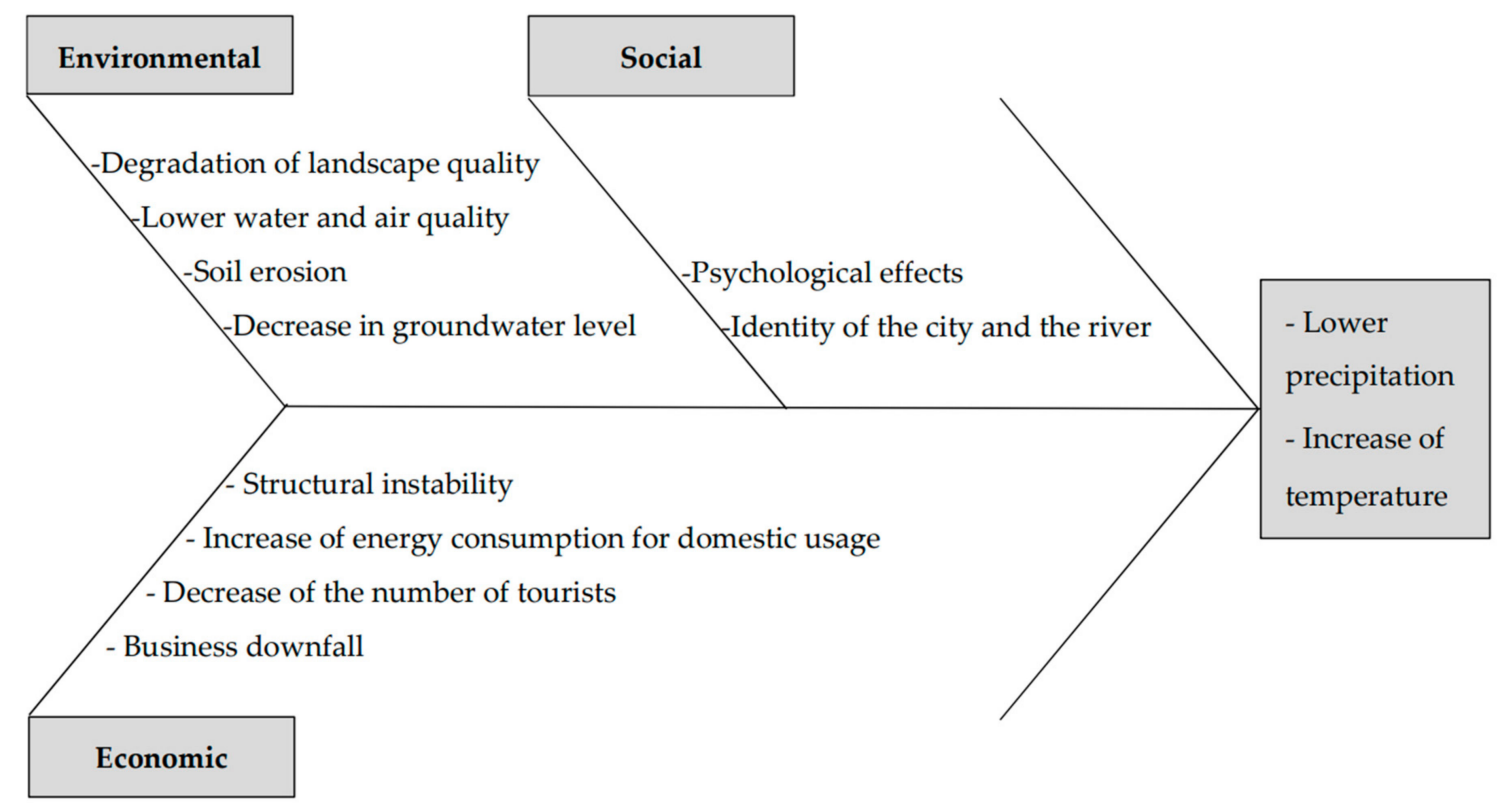

Figure 1. Cause and effect diagram for Zayanderood drought. 


\subsection{Risk Management}

Formulating an efficient risk management system is a major challenge for construction project managers [36]. In general, risk management is the process of assessing risk and then developing strategies for managing risk. In general, strategies for used risk management include transferring risk to other sectors, avoiding risk, mitigating the negative effects of risk, and accepting some or all of the consequences of a particular risk [37].

In occupational health \& safety assessment series (OHSAS) 18001, risk is a function of the probability and consequences of a specified hazardous event. The overall process of estimating risk and making decisions about risk tolerance is called risk assessment. The process of risk assessment acts as a bridge between proper risk assessment and the balanced management of major risks [38]. Risk assessment that has been carried out in this study followed the UK's health and safety executive (UK's HSE) model including four steps:

1. Identify risks;

2. Who may be harmed and how they will be harmed;

3. Risk assessment of risk;

4. Record the findings.

Risk assessment is a rational way to quantify the risks and examine consequences of potential accidents on individuals, materials, equipment, and the environment. Unfortunately, due to the predominance of physical factors, social aspects and their effects are typically being ignored by many risk assessors [33]. While, in order to applying the effectiveness of existing risk control methods and risk mitigation, it is a necessity to consideration and identifying of all aspects and possible risks. In general, risk assessment requires the calculation of two risk components; namely, severity of the event's outcome and the probability that the event will occur. There are three ways to gain probability weight or severity weight outcome:

1. Numerical methods that result in a number;

2. Qualitative methods that result in a certain quality in risk;

3. Semi-quantitative methods Most of these methods use the risk matrix [39].

This study used a semi-quantitative approach to risk assessment. In this context, the theoretical framework developed by Connelly et al. illustrated risk management approach for climate change adaptation (see Figure 2) [40]. This research defined probability as the chance of occurrence of the risk, while the presence of a hazard is not indicating the risk, but rather, a hazard only becomes a risk when a system is exposed to the hazard and is vulnerable to it should it be exposed. The following formula was addressed in advance:

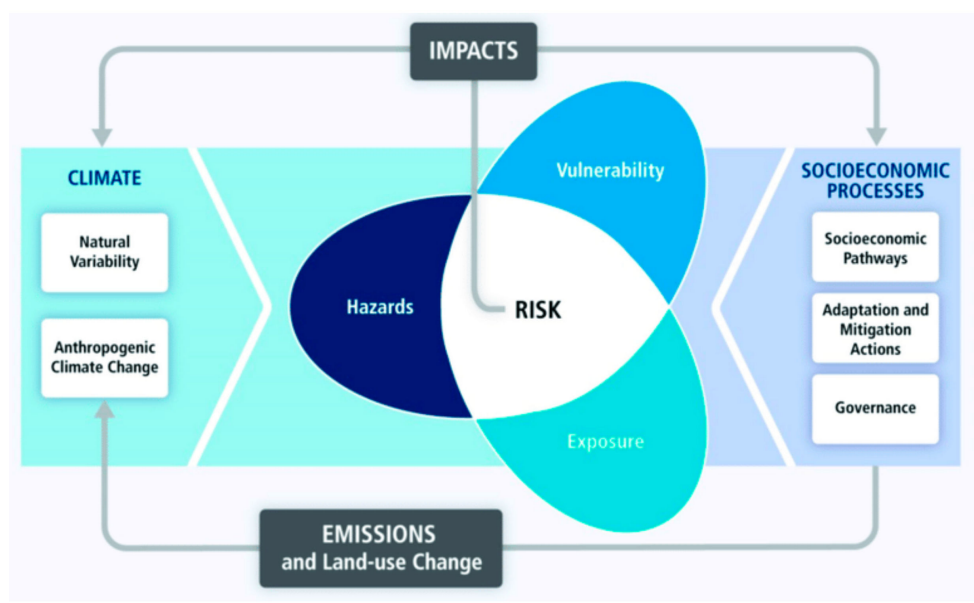

Figure 2. Risk management for climate change adaptation [40]. 
Risk $(\mathrm{R})=\mathrm{f}($ Probability of a Hazard $(\mathrm{p}), \times$ Exposure $(\mathrm{E}), \times$ Vulnerability $(\mathrm{V})$

\section{Research Methodology}

The research method consists of two stages. The first step is to identify the major risks of river drought. This phase consists of a comprehensive study of previous studies in the field of research, to identify and classify all risks associated with river drought. Important risks were identified through structured interviews and questionnaire distribution among experts. In the next step, weight and prioritize risks are identified. The network analysis process (ANP) is used to weigh the risks identified in the previous step. The ANP method was selected based on a comprehensive study of methods that could show the relationship between risk and feedback [41]. ANP approach is preferable in order to identify the problems of interdependence and feedback between various risk ranking alternatives [42]. Typically, the experts targeted by the ANP method determine the relationships between the indicators (here the indicators are referred as risks) based on their experience and expertise. However, failure to allocate appropriate relationships between risks and the multiplicity of them accordingly increase the likelihood of errors in the judgment and calculations of the experts while answering the pairwise questionnaire used by ANP. During this phase, the network of relationships between risks is formed. Thereafter, the interdependence of risks is based on sustainable development indicators. Finally, the weight of each risk is determined by pairwise comparisons based on the questionnaire. Figure 3 shows the two main steps of this research.

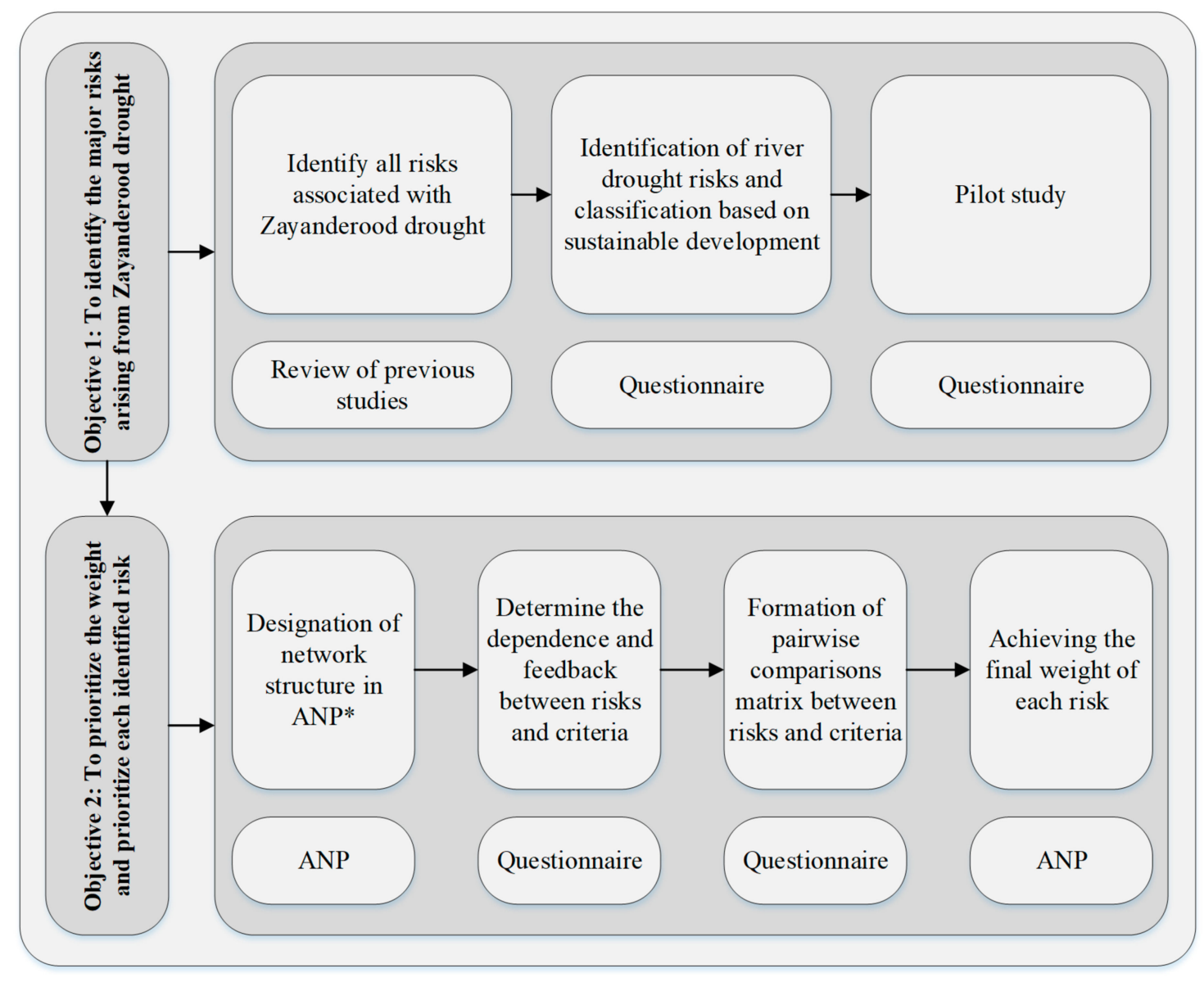

* Analytic Network Process (ANP)

Figure 3. Research framework. 


\subsection{Data Collection}

Data collection is one of the most important parts of any research project. True accomplishment of this on a regular basis would result in good speed and accuracy of data analysis. The data collection in this study was a combination of library and field methods as described next. The information needed is collected in two ways:

1. Receive expert opinions through questionnaire and interview;

2. Valid scientific sources, articles, bibliographies, etc.

The research questionnaire will be provided to the research experts and their comments will be obtained. In this study, the sample size is selected using the Cochran formula according to the unknown population [43]. To calculate the sample size, there must be an estimate of the size of $p$, which can be obtained from previous studies. Also, it can be estimated based on the experience of experts in the field or guiding study. If none of the above methods is feasible, assume $p=0.05$ to obtain the maximum number of samples possible [44]. In this study, the value of $p$ was considered equal to 0.05 .

$$
n=\frac{\frac{z^{2} p q}{d^{2}}}{1+\frac{1}{N}\left[\frac{z^{2} p q}{d^{2}}-1\right]}
$$

Wherein: $\mathrm{N}$ is the population volume; $\mathrm{z}=1 / 96 ; \mathrm{p}=\mathrm{q}=0.5 ; \mathrm{d}$ allowed error (error value). Thus, according to the unknown population, 65 people were selected as the sample size.

Cronbach's alpha coefficient was calculated by SPSS software to determine the reliability of the questionnaire based on the collected data. The results are visible in the table below (Table 1). The validity of the questionnaire was checked by expert opinions.

Table 1. Validity and reliability of research tools.

\begin{tabular}{ccc}
\hline Questionnaire & Validity & Reliability \\
\hline Factors Identification & Expert opinions & 0.84 (Cronbach's alpha) \\
Analytic Network Process (ANP) & Expert opinions & Consistency Rate (CR) \\
\hline
\end{tabular}

\section{Selection of Expert Panel}

The selection of the panel list and survey question formulations play a significant role in determining the reliability of the research. Experience and knowledge in the field of sustainable development and understanding of its issues are the most important criteria in deciding the credibility of the study. In order to ensure the credibility of this study, the respondents were carefully selected, based on criteria such as their degree, level of experience, and their profession (civil engineering, architecture, urban planning, academic economists and urban manager). The questionnaire was distributed to approximately 65 respondents. A total of 48 completed questionnaires by experts was collected, representing a success rate of $74 \%$.

Table 2 shows the background information of the respondents. These experts represent a vast spectrum of experts on environmental, social, and economic issues, and provide a balanced view for the questionnaire survey. As shown in Table 2, professional backgrounds of the participants mainly include civil engineering, architecture, and urban planning, although the presence of respondents from urban managers and academic economists reflects the comprehensiveness of respondents in all three aspects of sustainable development; namely, the economic, social and environmental aspects. Furthermore, more than $93 \%$ of them have more than five years experience in their sectors. 
Table 2. Background information of the respondents.

\begin{tabular}{ccc}
\hline \multirow{2}{*}{ Category } & \multicolumn{2}{c}{ Respondents } \\
\cline { 2 - 3 } & Frequency & Percentage \\
\hline Role (Profession) & & \\
Civil engineering & 17 & 35.42 \\
Architecture & 12 & 25.00 \\
Urban planning & 11 & 22.92 \\
Academic economists & 4 & 8.33 \\
Urban manager & 4 & 8.33 \\
Total & 48 & 100 \\
\hline Academic degree & & \\
Bachelor & 14 & 29.17 \\
Master & 21 & 43.75 \\
Doctorate & 13 & 27.08 \\
Total & 48 & 100 \\
\hline Experience level & & \\
Up to 5 years & 3 & 6.25 \\
6-10 years & 9 & 18.75 \\
11-15 years & 27 & 56.25 \\
More than 16 years & 9 & 18.75 \\
Total & 48 & 100 \\
\hline
\end{tabular}

\subsection{Risk Assessment}

Risk assessment determines the quantitative and qualitative value of the risks. It is clear that the results of this step determine the ability to properly manage the identified risk factors according to the circumstances. Risk assessment and prioritization determine the areas in which risk management should be more focused. In this study, evaluation and prioritization will be based on multi criteria decision making. An ANP technique was used for this purpose.

The ANP model was developed by Saaty to solve the analytical hierarchy process (AHP) model problem, which is an advanced model for decision making and analysis [45]. This model is capable of calculating the consistency of judgments and flexibility in the number of levels of judgment criteria. The ANP model is in fact the generalized model of the AHP hierarchical process analysis method, which does not follow AHP assumption about lack of relationship between different levels of decision making [46]. In this study, the Saaty judgment scale (Table 3) is used to express the significance of each risk.

Table 3. Fundamental Rating Scale of Thomas L. Saaty for Pair-wise Comparison Matrix [41].

\begin{tabular}{|c|c|c|}
\hline Intensity of Importance & Definition & Explanations \\
\hline 1 & Equal Importance & Two activities contribute equally to the objective \\
\hline 2 & Weak /Light & - \\
\hline 3 & Moderate Importance & $\begin{array}{c}\text { Experience and judgment slightly favor one } \\
\text { activity over another }\end{array}$ \\
\hline 4 & Moderate Plus & - \\
\hline 5 & Strong Importance & $\begin{array}{l}\text { Experience and judgment strongly favor one } \\
\text { activity over another }\end{array}$ \\
\hline 6 & Strong Plus & - \\
\hline 7 & $\begin{array}{l}\text { Very Strong or demonstrated } \\
\text { Importance }\end{array}$ & $\begin{array}{l}\text { An activity is favored very strongly over another, } \\
\text { its dominance demonstrated in practice }\end{array}$ \\
\hline 8 & Very, Very Strong & - \\
\hline 9 & Extreme Importance & $\begin{array}{l}\text { The evidence favoring one activity over another } \\
\text { is of the highest possible order of affirmation. }\end{array}$ \\
\hline
\end{tabular}




\section{Description of Using ANP for Risk Assessment}

In order to consider the dependencies and feedback between the risks and the criteria, it is necessary to examine the risk assessment tools, techniques, and their capabilities. Given the high potential of the ANP method in decision-making applications, and considering dependency among factors, it was used for data analysis. Important risks identified were weighted based on their dependence and feedback. The weight and final ranking of risks were obtained through the Super Decisions software. Based on the assumptions and the research method, data analysis was started after identifying the criteria influencing risk prioritization. To do this, a questionnaire survey was provided to distribution among existing experts in the fields of architecture, civil engineering, and urban planning based in municipalities and affiliated companies. The research and ranking the risks of the Zayanderood drought by ANP method are summarized as follows:

Step 1: Determine clusters, elements, and sub-elements to be initially used in the recommended model. The key selection elements and sub-elements are determined in this step by experts. In the model network decision, one set of elements is involved: one element and one sub-cluster are determined for the criteria. These elements are identified as optimal risk allocation criteria.

Step 2: Build an ANP network structure, including clusters, elements, sub-elements, and alternatives utilizing Super Decisions software.

Step 3: Obtain a pairwise comparison matrices between various groups and the various risk factors within the same group. These comparisons were collected in comparison matrices. The following question was asked of the expert team to compare each criteria group and criteria factors with attention to their impact on the risk assessment of each risk. The experts were asked to perform a pairwise comparison using an ANP scale (1-9). To reflect the interdependencies of this simple network, pairwise comparisons among all the groups and risk factors were performed, and these relationships were evaluated. The averages of the answers were inserted into the Super Decision software to calculate consistency of pairwise comparison matrices. Consistency rate (CR) was used to check consistency according to the pairwise comparison. If the value of $C R$ was less than 0.1 , it indicated that such a pairwise comparison matrix contained satisfactory consistency [41].

Step 4: The next step is to create un-weighted, weighted, and limit super-matrices of all the elements within a network structure. The un-weighted super-matrix includes the local priorities insulated from the pairwise comparisons. Influence priority is assigned as zero when an element has no influence on another element [36]. Multiplying the cluster weights to their relative blocks in the un-weighted super-matrix yields the weighted matrix. In this method, the component is weighted with its corresponding cluster matrix weight. Then, the weighted super-matrix must be converted to a limited matrix by raising the weighted super-matrix to powers [38]. The results of the priorities are extracted and obtained from the limit matrix. The above computing process is accomplished using Super Decision software. Finally, the final ranking of each risk factor using ANP weights are obtained in this stage.

Super Decisions implement the ANP. It is decision-making software which works based on two multi-criteria decision-making methods: AHP and ANP [41]. The Super Decisions software is used for decision-making with dependence and feedback. This software provides tools to create and manage ANP models, enter judgments, obtain results, and perform sensitivity analysis on those results. Super Decisions software has been applied by many researchers in the fields of risk management and sustainable decision-making, such as water safety and health, social and economic risk assessment, and flood hazard (e.g., [42,45,47-50]). In this study, all of the second, third, and fourth steps were conducted by Super Decisions software.

\subsection{Area of the Research}

Iran is located in an arid zone and has faced a serious water shortage crisis over the past several years. Its precipitation is approximately one third of the global average, and distribution of monthly rainfall has changed in recent years. The drought in Iran has become one of the most important 
problems in the country, which is experiencing a range of drastic environmental, social, and economic problems in need of being urgently addressed [51].

The Zayanderood is the largest river of the Iranian Plateau in central Iran. The Zayanderood riverside has always been the center of all social and economic activities in Isfahan, one of Iran's main tourist attractions. $80 \%$ of the Zayanderood extracted water is used for agriculture, $10 \%$ for human consumption (drinking and domestic needs of a population of 4.5 million), $7 \%$ for industry, and $3 \%$ for other uses [52].

The Zayanderood once had significant flow all year long, unlike many of Iran's rivers which are seasonal. In the early 2010s, the lower reaches of the river dried out completely after several years of seasonal dryouts. After 14 consecutive years of hydrologic droughts and climate change, parts of the river in areas near Isfahan have turned into dry riverbed.

Drought has damaged the agriculture sector severely in this region, because when drought occurs, the residential and industry sectors are given priority. On the other hand, the upstream section of the river after Zayanderood dam does not experience any water limitation in times of drought; therefore, the full impact of drought pressures is imposed on the downstream section of the river [53]. Moreover, drought causes many problems for the population, as dust storms are frequently observed in those areas. Besides, the water shortage problem further complicates the daily life of the people. The area of research is shown in Figure 4.

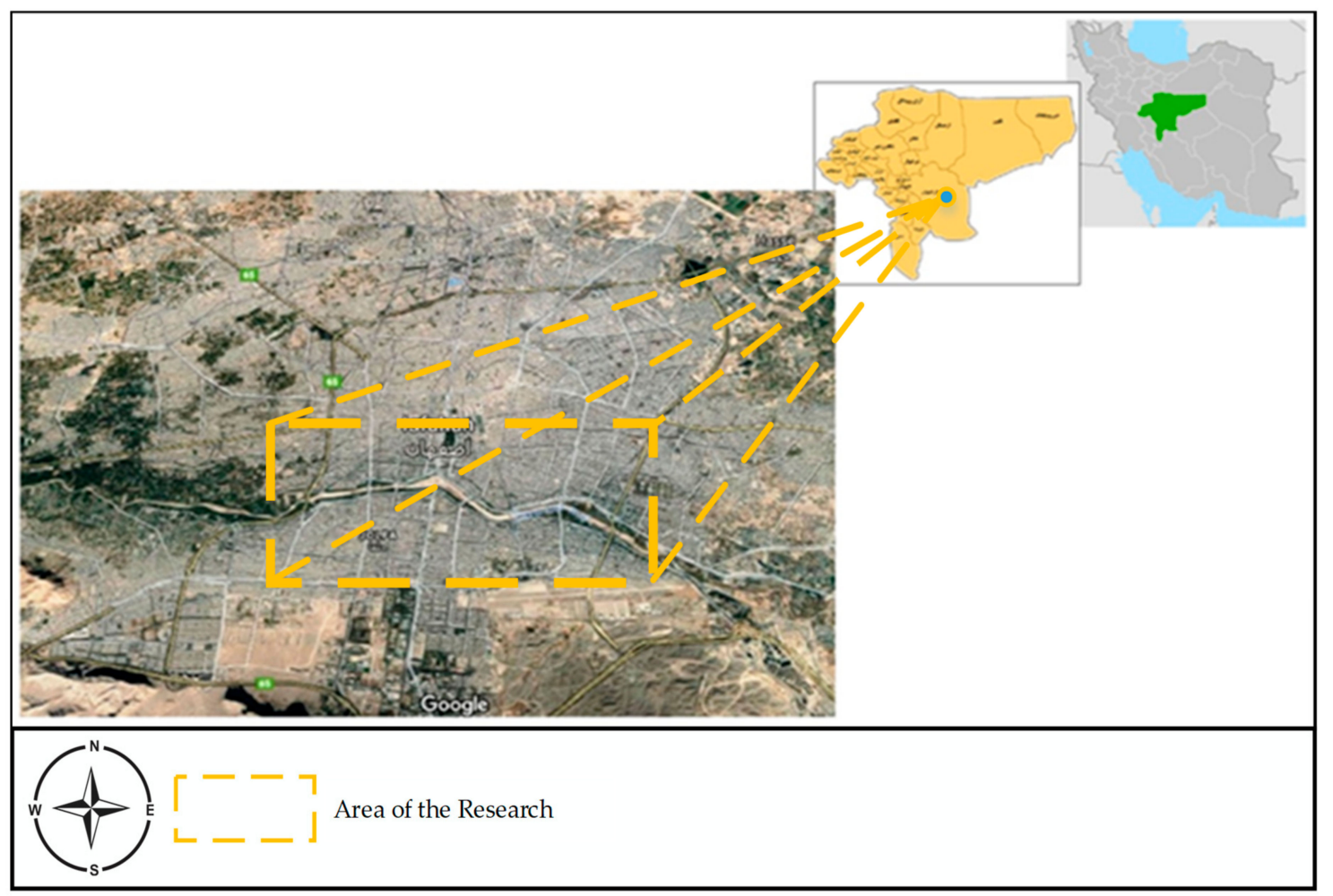

Figure 4. Area of the research.

In principle, continuation of the Zayanderood drought process has negative effects on social, economic, and environmental aspects. Therefore, considering the importance of this issue, it can be concluded that this issue is vital for the sustainability of Isfahan.

The study area comprises, on average, a $500 \mathrm{~m}$ radius of the northern and southern margins of the Zayanderood River in Isfahan. This area includes buildings with different uses that are clearly displayed on the user map. As shown in the map (Figure 5), the use of buildings in the study area includes residential, commercial, educational, administrative, religious, health, cultural, hotel, tourism, and outdoor uses, with the most residential use being in this area. 


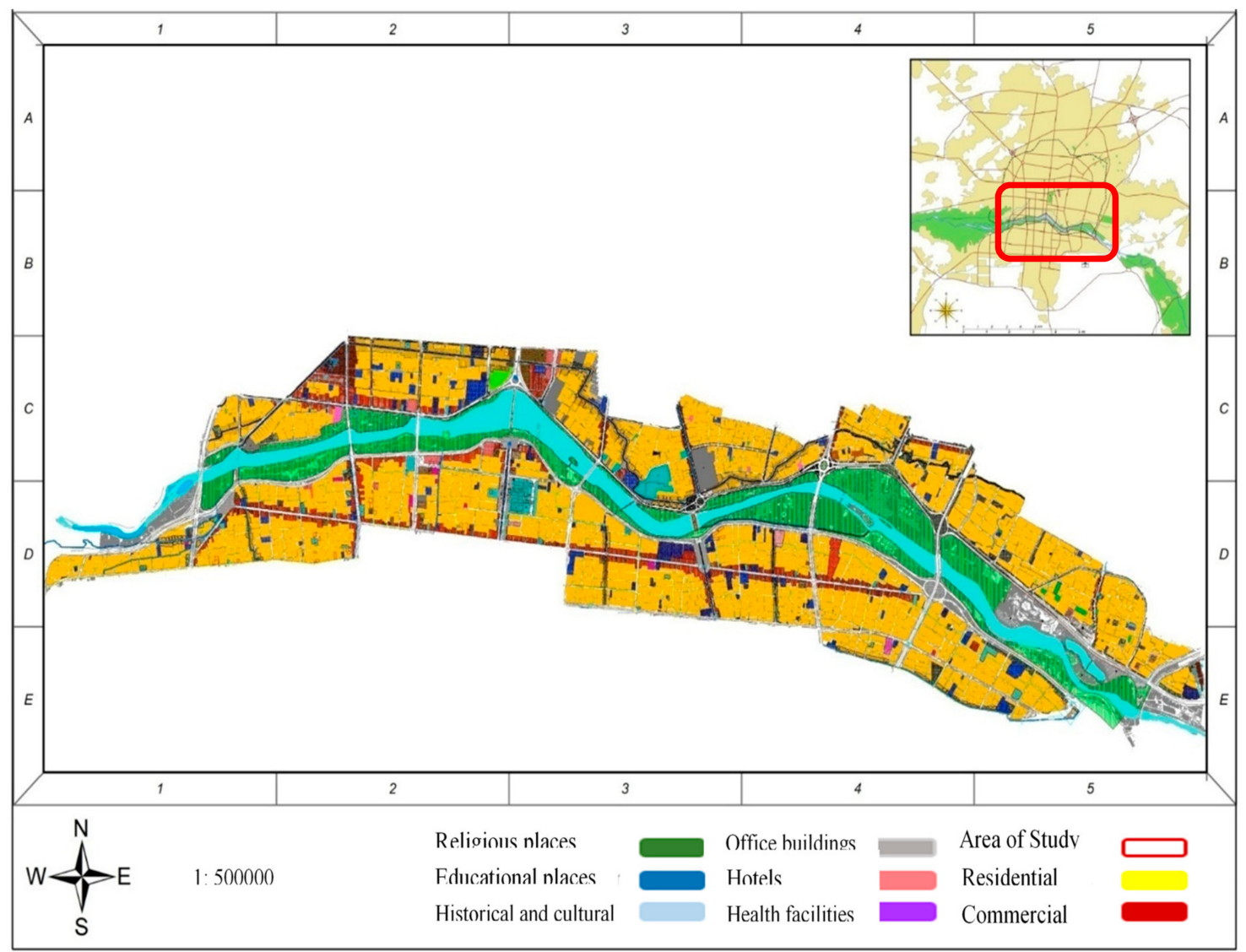

Figure 5. Buildings within the study area.

\section{Results and Discussion}

In order to examine the risks affecting the sustainable development indicators, examining the relevant literature thoroughly and comprehensively was attempted. Although there have been good researches on the subject under study, according to other studies, it can be said that in scale with other natural crises, the issue of river drought and its effects on sustainable development have never been studied. However, using the available research background and theoretical foundations, there were 26 risks arising from the effects of surface and groundwater drought on the river. These risks are divided into three main sustainable development groups (environmental, social, and economic). Out of the 26 identified risks, 17 are related to the environmental category, 6 are social-related, and 3 are economic. Therefore, it can be said from a general perspective that from previous studies, the effects of hydrological drought of the river base have the greatest impact on environmental and social indices, while at the same time there are many economic risks in regards to urban sustainable development (Table 4).

A questionnaire (Appendix A) was designed to identify the sub-criteria and was distributed among specialists. The work was conducted through a structured interview to ensure that respondents had a full understanding of the questions. Then, the final sub-criteria were identified by collecting the questionnaires. It should be noted that the risk has been calculated as the results of multiplying three dimensions (effects, proneness, and exposure) that were included in the distributed questionnaires. Risks and their attributed weight have been illustrated in a scatter diagram, shown in Figure 6 . Blue dots in Figure 6 represent the risk factors, and their attributed number is the number of each risk factor according to Table 4. As shown in Figure 6, eight risks have been located at the left side of the risk limit line. The risk assessor in this research opted to eliminate risk below 18 as unimportant or effective risks. The risk limit line is obtained by calculating the standard deviation of all values, which is 18.18 . 
Table 4. Risks identified from the research literature and experts' opinion.

\begin{tabular}{|c|c|c|c|c|}
\hline No. & Criteria & Sub Criteria & Questionnaire Result & Code \\
\hline 1 & \multirow{17}{*}{ Environmental } & Soil drying & Confirmation & SD \\
\hline 2 & & Degradation and erosion of soil & Confirmation & DES \\
\hline 3 & & Lowering the static ground water level & Confirmation & DUWL \\
\hline 4 & & Climatic change & Confirmation & $\mathrm{CC}$ \\
\hline 5 & & The gradual land subsidence & Confirmation & GSE \\
\hline 6 & & building structures damage, especially old buildings & Confirmation & DBS \\
\hline 7 & & $\begin{array}{c}\text { Risk of sudden collapse and all construction being } \\
\text { overshadowed }\end{array}$ & disapproval & - \\
\hline 8 & & Creating gaps in the building and the ground & Confirmation & CGG \\
\hline 9 & & Reducing the quantity and quality of drinking water & disapproval & - \\
\hline 10 & & Wastewater problems due to drought & disapproval & - \\
\hline 11 & & Air pollution, dust & Confirmation & APDF \\
\hline 12 & & wells drying & Confirmation & WD \\
\hline 13 & & Material drying & disapproval & - \\
\hline 14 & & $\begin{array}{l}\text { Changes in ground seismic Impacts due to } \\
\text { Climatic Changes }\end{array}$ & disapproval & - \\
\hline 15 & & Damages to construction installation & Confirmation & DBFN \\
\hline 16 & & $\begin{array}{l}\text { Impact of Climatic Changes on Building Materials } \\
\text { (Crack in Concrete, Bricks, and ... ) }\end{array}$ & disapproval & - \\
\hline 17 & & $\begin{array}{l}\text { Impact of climatic change (increasing temperature) } \\
\text { on building performance (energy consumption) }\end{array}$ & disapproval & - \\
\hline 18 & \multirow{6}{*}{ Social } & $\begin{array}{l}\text { Reducing residents' sense of interest for returning to } \\
\text { river side urban spaces }\end{array}$ & Confirmation & RAPR \\
\hline 19 & & Threatening the lives of riverside local communities & disapproval & - \\
\hline 20 & & Increasing residents' illness affliction & Confirmation & IIDCR \\
\hline 21 & & A serious threat about Zayanderood identity & Confirmation & STIR \\
\hline 22 & & Reducing the aesthetic value of the view & Confirmation & RAVL \\
\hline 23 & & Degrading the quality of life & Confirmation & DRQ \\
\hline 24 & \multirow{3}{*}{ Economic } & $\begin{array}{l}\text { Tourism industry degrades (decrease in tourist } \\
\text { attraction and the period of their presence) }\end{array}$ & Confirmation & LITI \\
\hline 25 & & Migration & Confirmation & M \\
\hline 26 & & $\begin{array}{l}\text { Disturbing the Economic Balance of beneficiary } \\
\text { Communities (Reducing job Creation) }\end{array}$ & Confirmation & RJCOE \\
\hline
\end{tabular}

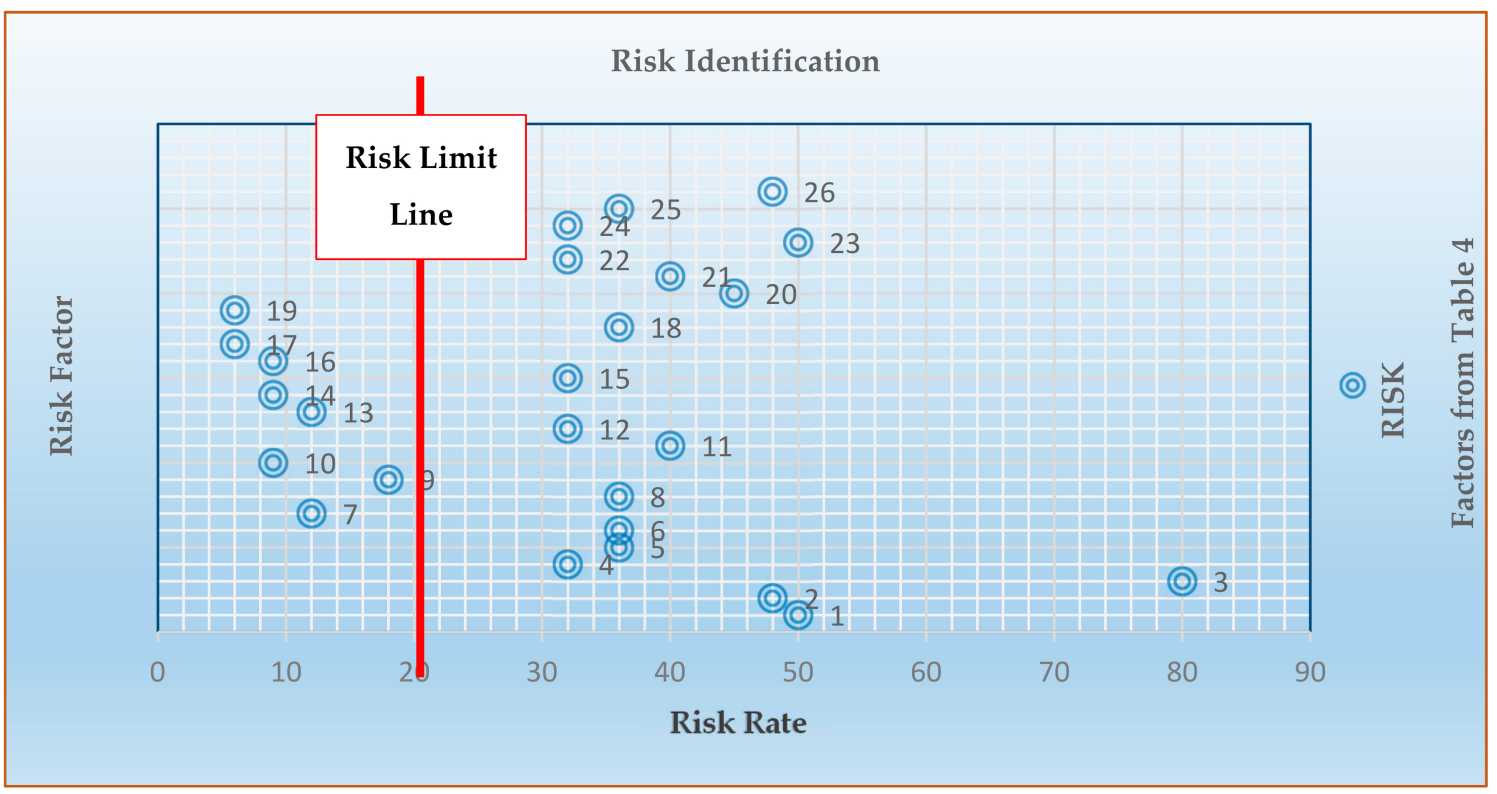

Figure 6. Risk identification for Zayanderood river drought. 
According to the results of the initial questionnaire, 8 sub-criteria were not approved by experts and experts related to the problem. As a result, there are 18 sub-criteria (out of 18 factors, 10 are related to the environmental category, 5 are social-related, and 3 are economic) that influence the evaluation, which are then examined using ANP. After confirming the effective criteria, the second questionnaire (Appendix B) addressing the experts was conducted as well. The relationships between the sub-criteria were determined, and then the opinions of 48 research experts were collected based on the second questionnaire (Figure 7 is an example of the relationships depicted in the ANP model using Super Decision software). In this section, we compiled tables from the combination of 48 respondents who responded to this questionnaire, each of which has a pair of comparative matrix houses from the geometric mean of 48 respondents. The geometric mean of the different views makes the incompatibility rate of each matrix smaller than the incompatibility rate of the pairwise comparisons of each individual.

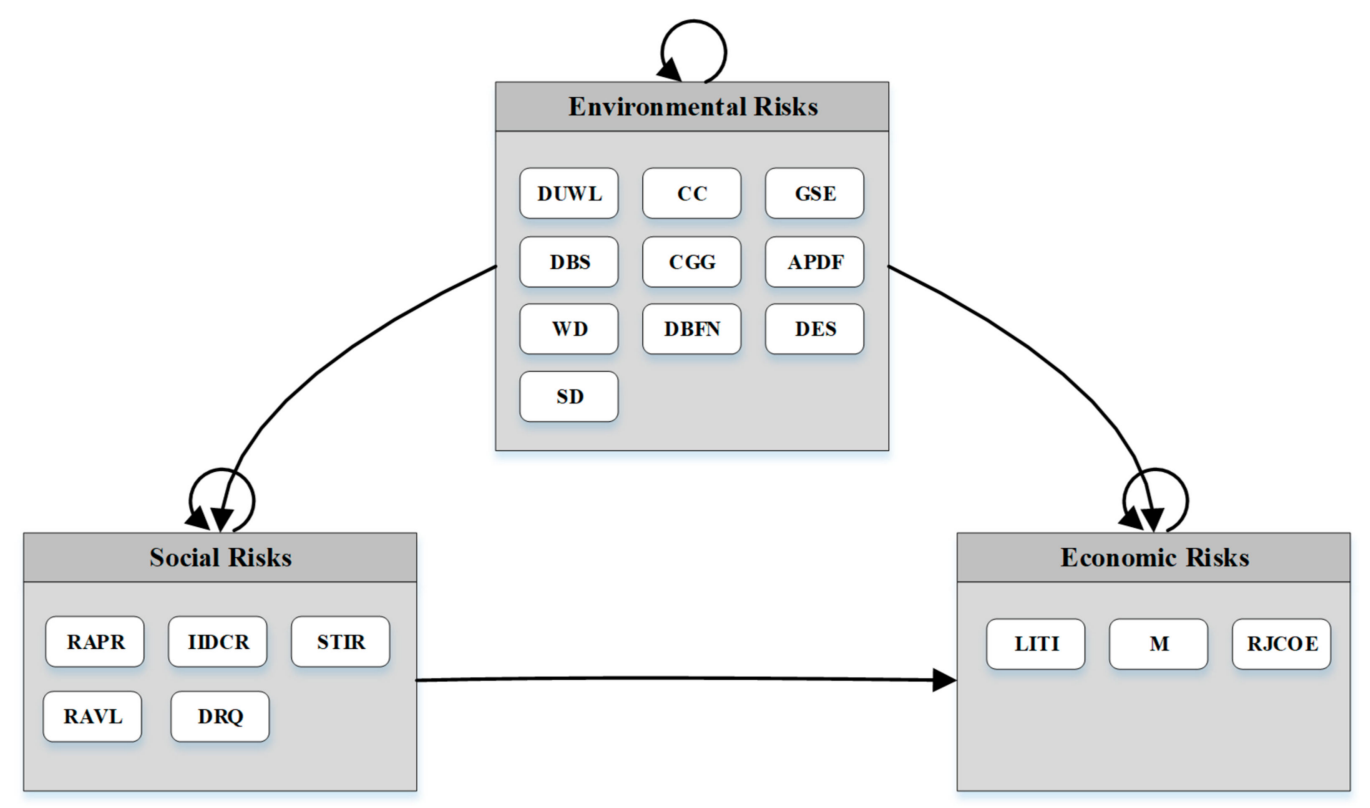

Figure 7. Inter/outer relationship among criteria and sub-criteria using Super Decisions software.

\subsection{Criteria and Sub Criteria Prioritization}

As can be seen in Table 5, the criteria and sub-criteria were ranked according to their final weight in the Super Decisions software. Figure 8 also shows the weighting of the main environmental, social sustainability, and economic sustainability indicators.

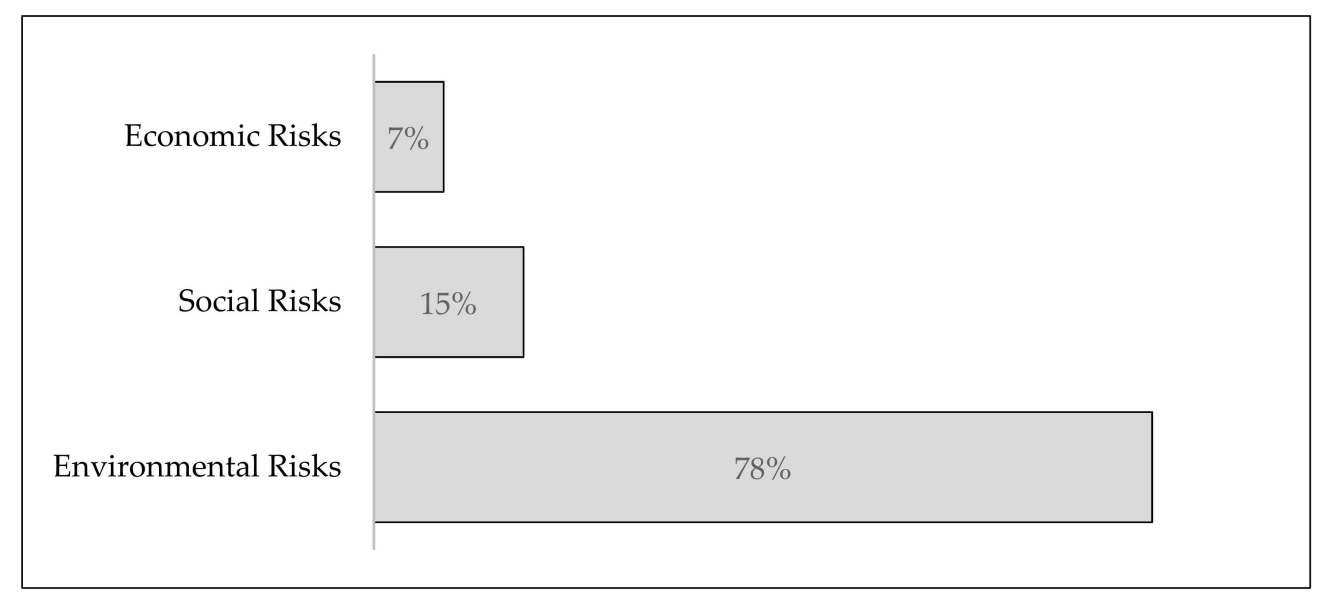

Figure 8. The weight of main criteria. 
Table 5. The weight and rank of criteria and sub-criteria.

\begin{tabular}{|c|c|c|c|c|c|c|}
\hline No. & Criteria & $\begin{array}{l}\text { Criterion } \\
\text { Weight }\end{array}$ & $\begin{array}{l}\text { Criterion } \\
\text { Ranking }\end{array}$ & Sub-Criteria & $\begin{array}{c}\text { Weight of } \\
\text { Sub-Criteria }\end{array}$ & $\begin{array}{c}\text { Rank of } \\
\text { Sub-Criteria }\end{array}$ \\
\hline 1 & \multirow{10}{*}{ Environmental } & \multirow{10}{*}{0.7884} & \multirow{10}{*}{1} & Soil drying & 0.0223 & 12 \\
\hline 2 & & & & Degradation and erosion of soil & 0.182 & 13 \\
\hline 3 & & & & Lowering the static ground water level & 0.1717 & 1 \\
\hline 4 & & & & The gradual land subsidence & 0.1219 & 3 \\
\hline 5 & & & & $\begin{array}{c}\text { Damage of building structures, especially } \\
\text { old buildings }\end{array}$ & 0.0923 & 4 \\
\hline 6 & & & & $\begin{array}{l}\text { Creating gaps in the building and } \\
\text { the ground }\end{array}$ & 0.498 & 8 \\
\hline 7 & & & & Air pollution, dust & 0.0829 & 7 \\
\hline 8 & & & & Damage to construction installation network & 0.0873 & 6 \\
\hline 9 & & & & wells drying & 0.0095 & 17 \\
\hline 10 & & & & Climate Change & 0.1325 & 2 \\
\hline 11 & \multirow{5}{*}{ Social } & \multirow{5}{*}{0.1483} & \multirow{5}{*}{2} & $\begin{array}{l}\text { Reduce residents' sense of attachment for } \\
\text { access to urban spaces along the riverside }\end{array}$ & 0.0263 & 11 \\
\hline 12 & & & & Increase of catching the residents' illness & 0.0887 & 5 \\
\hline 13 & & & & $\begin{array}{l}\text { A serious threat about the Zayanderood } \\
\text { identity and Isfahan city }\end{array}$ & 0.0133 & 16 \\
\hline 14 & & & & $\begin{array}{c}\text { Reducing the aesthetic value of the view } \\
\text { along the riverside }\end{array}$ & 0.0141 & 14 \\
\hline 15 & & & & $\begin{array}{l}\text { Decreased quality of life in the } \\
\text { residential environment }\end{array}$ & 0.0322 & 10 \\
\hline 16 & \multirow{3}{*}{ Economic } & \multirow{3}{*}{0.0666} & \multirow{3}{*}{3} & Less revenue from the tourism industry & 0.0443 & 9 \\
\hline 17 & & & & migration & 0.0078 & 18 \\
\hline 18 & & & & $\begin{array}{l}\text { Reducing employment creation and } \\
\text { disturbing the economic balance of } \\
\text { beneficiaries communities }\end{array}$ & 0.0136 & 15 \\
\hline
\end{tabular}

\subsection{Data Validation}

Numerous methods have been used to validate prioritization results from the ANP model, including use of the statistical method in the study by Fuertes et al. [54], and comparison to other methods such as studies developed by Sun and Meng [55] and Juan et al. [56], and application of VIKOR (Vlse Kriterijumska Optimizacija Kompromisno Resenje which means multi criteria optimization and compromise solution, in Serbian) in the study by Mohammadi et al. [57]. In order data validation, the authors found the use of a statistical method to be appropriate for this study.

For this purpose, a survey is developed to evaluate the expert satisfaction from ranking with the ANP model while comparing that with the primary risk assessment carried out by the first questionnaire. The respondent of the evaluation survey included 2 members with civil engineering backgrounds, an economist, and 3 urban planning professionals (designers and planners). Evaluators are assessed and selected based on their level of experience, background, and their authorization. The results showed that the rate of satisfaction among the evaluators is 0.89 . Evaluation criteria and responses of the experts are represented in Table 6.

Table 6. Evaluation of risk prioritization with Analytic Network Process (ANP).

\begin{tabular}{ccccccccc}
\hline Criteria & Expert1 & Expert2 & Expert3 & Expert4 & Expert5 & Expert6 & Sum & Percent \\
\hline Accuracy of results & 5 & 5 & 5 & 5 & 5 & 4 & 29 & 95 \\
Time spent to respond & 5 & 3 & 4 & 5 & 5 & 5 & 27 & 90 \\
Complexity to respond & 4 & 3 & 3 & 5 & 5 & 5 & 25 & 83 \\
$\quad \begin{array}{c}\text { Understandability } \\
\text { of questions }\end{array}$ & 5 & 4 & 5 & 4 & 4 & 5 & 27 & 90 \\
Flexibility of questions & 4 & 4 & 4 & 5 & 4 & 5 & 26 & 87 \\
\hline Average & & & & & & & & 89 \\
\hline
\end{tabular}




\section{Conclusions}

Drought is one of the climatic events that exhibit different forms in the vast expanse of Iran, influencing the natural life of its inhabitants. Drought, rising temperatures, and evapotranspiration, increased consumption patterns, and poor management are the fundamental elements of a water crisis. Zayanderood River, because of these reasons, is faced with severe economic and social challenges, and management of water resources. Although much research has been done by previous researchers on the origin of drought and its associated risks, the originality and innovation of the present study is to adopt a risk-based approach to identify and prioritize the risk of drought impacts on sustainable development indicators of its surrounding buildings. This study seeks to improve previous results by examining dependence, feedback, and interaction between risks. The results of this study play a significant role in the management of the drought crisis. Such results enable the decision maker to make deeper decisions, such as focusing on important priorities and finding possible alternative solutions. Drawing risk-based policies can reduce the level of damage in this regard. The key findings and main results of the present study are summarized as follows:

The first objective of this study was to identify and classify the risks associated with the Zayanderood drought affecting sustainable development indices. First, a comprehensive study of past literature was conducted to identify the risks associated with river drought, and in particular the risks of groundwater depletion. Several face-to-face interviews were held with experienced civil, architectural, and urban design professionals. Based on the findings of previous studies, 26 risks were identified, which were reduced to 18 important risks according to the results of the questionnaire distributed. These risks were classified into three groups according to sustainable development indicators. These include environmental, social, and economic. The most important results for this purpose are summarized below:

1. A comprehensive study on the Zayanderood was conducted to identify related risks;

2. To identify the significant risks structured interviews with industry experts has been done;

3. In general, 18 important and key risks associated with drought were identified;

4. Risks were categorized into three environmental, social, and economic groups.

The second purpose of this study was to determine the weight of each of the major risks based on the dependence and feedback between the risks and the indicators. Analytic Network Process (ANP) method was chosen for data analysis because of its ability to consider the dependence between criteria and sub-criteria. The network structure was formed by a panel of experts in different fields, including civil engineering, architecture, and urban planning to illustrate the interaction between risks. At the same time, a pairwise comparison questionnaire was developed to determine the degree of importance of each risk. After the questionnaires were distributed and collected, Super Decision software was used for data analysis. The weight of each risk was obtained according to three environmental, social, and economic indicators. In fact, the weight of each risk reflects the impact of that risk on sustainable development indicators. Among the 18 identified risks, environmental risks were the most weighted and social, and economic risks ranked in second and third place. Identified risks were then assessed and prioritized. The set weights were considered their final ranking.

The analysis the ranking of the risks associated with the Zayanderood droughts represented a significant impact of the drought on underground water level. The sub-criterion weight ad 0.1717 in this model. Climate change with the weight of 0.1325 and gradual subsidence of land with the weight of 0.1219 ranked in second and third place. Devastating effects on the structure which were considered in three sub-criteria, including of structural defects especially in old buildings, defects in installations, and creating cracks between structure and foundation attained fourth, sixth, and eighth rankings. On the other side, the effects on immigration with the weight of 0.0078 , drying of well sheds with the weight of 0.0095 , and negative impact on river identity with the weight of 0.0013 were identified as least important impacts of the drought, respectively. 
The analysis confirms the interplay between climate change and the Zayanderood drought in a way that any of them give rise to the other one. The fact can be interpreted from Figure 1 as well. Decrease in participation rate and increase of temperature act as both cause and effect of the drought. As the participation rate decreases and the temperature rises, the drought will increase, and with the continuing trend of drought and river evaporation the weather will become hotter and participation would be reduced. In later stages, this can lead to secondary effects, such as increased disease burden and lower quality of life. On the other hand, as the effect of the Zayanderood drought crisis has been noted in many previous studies (including [20-22]) the impact of this crisis on the level and storage of groundwater levels was determined as very high by this study. The issue requires serious consideration and specific control measures to manage the risk. Since, in addition to the destructive impact of this factor on other environmental factors such as climatic conditions, soil subsidence, damage to the installation network, and the structure of buildings, this factor causes other consequences in social contexts and material damages. Therefore, it can be concluded that the negative impact of the drought crisis on the groundwater table is the most important and fundamental consequence of this crisis. With this regard, particular attention should be paid to the issue of river drought based on sustainable development concerns.

Due to the city of Isfahan facing the problem of climate change, it is suggested that urban buildings adopt and adapt more to the current and future conditions in the construction industry, refurbishment, and improvement in accordance with the circumstances.

Author Contributions: Conceptualization: H.S.; Software: H.S.; Formal analysis: H.S. and M.R.; Investigation: J.T.; Methodology: H.S. and D.W.M.C.; Data Curation: H.S.; Writing-original draft preparation: H.S.; Visualization: H.S.; Validation: M.R. and J.T.; Resources: M.B. and J.T.; Writing-review and editing: M.R., J.T., M.B. and D.W.M.C.; Supervision: M.B.; Project administration: J.T.

Funding: This research received no external funding.

Conflicts of Interest: The authors declare no conflict of interest.

\section{Appendix A. Questionnaire on the Risk Identification (Questionnaire 1)}

Dear Expert,

The purpose of this survey is to identify a complete list of risk factors affecting sustainable development indicators due to Zayanderood Drought. How much do you agree with the following factors? (Intensity of Importance: 1 = Not Important; 2 = Low Important; 3 = Moderately Important; $4=$ Important; 5 = Very Important).

\begin{tabular}{|c|c|c|c|c|c|c|c|c|c|c|c|c|c|c|c|c|c|}
\hline \multirow{2}{*}{ No. } & \multirow{2}{*}{ Criteria } & \multirow{2}{*}{ Sub criteria } & \multicolumn{5}{|c|}{ Probability } & \multicolumn{5}{|c|}{ Exposure } & \multicolumn{5}{|c|}{ Vulnerability } \\
\hline & & & 1 & 2 & 3 & 4 & 5 & 1 & 2 & 3 & 4 & 5 & 1 & 2 & 3 & 4 & 5 \\
\hline 1 & \multirow{10}{*}{ Environmental } & Soil drying & & & & & & & & & & & & & & & \\
\hline 2 & & Degradation and erosion of soil & & & & & & & & & & & & & & & \\
\hline 3 & & Lowering the static ground water level & & & & & & & & & & & & & & & \\
\hline 4 & & Climatic change & & & & & & & & & & & & & & & \\
\hline 5 & & The gradual land subsidence & & & & & & & & & & & & & & & \\
\hline 6 & & $\begin{array}{l}\text { building structures damage, especially } \\
\text { old buildings }\end{array}$ & & & & & & & & & & & & & & & \\
\hline 7 & & $\begin{array}{l}\text { Risk of sudden collapse and all } \\
\text { construction being overshadowed }\end{array}$ & & & & & & & & & & & & & & & \\
\hline 8 & & $\begin{array}{l}\text { Creating gaps in the building and } \\
\text { the ground }\end{array}$ & & & & & & & & & & & & & & & \\
\hline 9 & & $\begin{array}{l}\text { Reducing the quantity and quality } \\
\text { of drink... }\end{array}$ & & & & & & & & & & & & & & & \\
\hline 10 & & Wastewater problems due to drought & & & & & & & & & & & & & & & \\
\hline
\end{tabular}




\begin{tabular}{|c|c|c|c|c|c|c|c|c|c|c|c|c|c|c|c|c|c|}
\hline No. & Criteria & Sub criteria & \multicolumn{5}{|c|}{ Probability } & \multicolumn{5}{|c|}{ Exposure } & \multicolumn{5}{|c|}{ Vulnerability } \\
\hline 11 & & Air pollution, dust & & & & & & & & & & & & & & & \\
\hline 12 & & wells drying & & & & & & & & & & & & & & & \\
\hline 13 & & Material drying & & & & & & & & & & & & & & & \\
\hline 15 & & Damages to construction installation & & & & & & & & & & & & & & & \\
\hline 16 & & $\begin{array}{l}\text { Impact of Climatic Changes on Building } \\
\text { Materials (Crack in Concrete, Bricks, etc) }\end{array}$ & & & & & & & & & & & & & & & \\
\hline 17 & & $\begin{array}{l}\text { Impact of climatic change (increasing } \\
\text { temperature) on building performance... }\end{array}$ & & & & & & & & & & & & & & & \\
\hline 19 & \multirow{5}{*}{ Social } & Threatening the lives of riverside local ... & & & & & & & & & & & & & & & \\
\hline 20 & & Increasing residents' illness affliction & & & & & & & & & & & & & & & \\
\hline 21 & & $\begin{array}{l}\text { A serious threat about } \\
\text { Zayanderood identity }\end{array}$ & & & & & & & & & & & & & & & \\
\hline 22 & & Reducing the aesthetic value of the view & & & & & & & & & & & & & & & \\
\hline 23 & & Degrading the quality of life & & & & & & & & & & & & & & & \\
\hline 24 & Economic & $\begin{array}{l}\text { Tourism industry degrades (decrease in } \\
\text { tourist attraction and the period of } \\
\text { their presence) }\end{array}$ & & & & & & & & & & & & & & & \\
\hline
\end{tabular}

\section{Appendix B. An Example of Pairwise Comparison Questionnaire}

\section{Dear Expert,}

The purpose of this pairwise comparison is to determine of the importance of sub criterion according to sub criterion of air pollution and dust in social group. For example: What is the importance of Increasing residents' illness affliction to the Degrading the quality of life, according to the due to air pollution and dust? (Intensity of Importance: 1 = Equal Importance; 2 = Weak/Light; 3 = Moderate Importance; $4=$ Moderate Plus; $5=$ Strong Importance; $6=$ Strong Plus; $7=$ Very Strong or Demonstrated Importance; 8 = Very, Very Strong; 9 = Extreme Importance).

\begin{tabular}{|c|c|c|c|c|c|c|c|c|c|c|c|c|c|c|c|c|c|c|c|}
\hline \multicolumn{20}{|c|}{ Sub Criterion of Air Pollution and Dust } \\
\hline 2 & Degrading the quality of life & 9 & 8 & 7 & 6 & 5 & 4 & 3 & 2 & 1 & 2 & 3 & 4 & 5 & 6 & 7 & 8 & 9 & Reducing the aesthetic value of the view \\
\hline 4 & Increasing residents' illness affliction & 9 & 8 & 7 & 6 & 5 & 4 & 3 & 2 & 1 & 2 & 3 & 4 & 5 & 6 & 7 & 8 & 9 & Reducing the aesthetic value of the view \\
\hline 6 & Reducing the aesthetic value of the view & 9 & 8 & 7 & 6 & 5 & 4 & 3 & 2 & 1 & 2 & 3 & 4 & 5 & 6 & 7 & 8 & 9 & $\begin{array}{c}\text { Threatening the lives of riverside } \\
\text { local communities }\end{array}$ \\
\hline
\end{tabular}




\section{References}

1. Haji, A.K.S.; Fotouhi, O.Z.; Hajian, E.; Azani, M. Zayandehrood Land Survey on Sustainable Tourism Development in Isfahan. In Proceedings of the Twelfth Iranian Geographical Society Congress on Land Planning, Islamic Azad University, Najafabad Branch, Najafabad, Iran, 3-4 March 2015. (In Persian).

2. Rostamian, Z.; Khosravi, P.B. The Impact of Drought on Sustainable Development. In Proceedings of the First International Conference on Applied Research in Agriculture, Natural Resources and Environment, Management and Planning Organization, Hamadan, Iran, 14 July 2017. (In Persian).

3. Ghasemzadeh, B.; Pajouhan, M.; Hatami Nejad, H.; Sajjadzadeh, H. The Impact of Rising Drought on Social Interactions and Public Spaces in Isfahan. Ecology 2014, 40, 481-498. (In Persian)

4. Feng, Q.-Y.; Liu, G.-J.; Meng, L.; Fu, E.-J.; Zhang, H.-R.; Zhang, K.-F. Land subsidence induced by groundwater extraction and building damage level assessment-A case study of Datun, China. J. China Univ. Min. Technol. 2008, 18, 556-560. [CrossRef]

5. Cramer, W.; Guiot, J.; Fader, M.; Garrabou, J.; Gattuso, J.-P.; Iglesias, A.; Xoplaki, E. Climate change and interconnected risks to sustainable development in the Mediterranean. Nat. Clim. Chang. 2018, 8, 972-980. [CrossRef]

6. Lwoga, N.B.; Asubisye, E. Effects of drought on cultural tourism: Selected cases of Maasai tourism groups surrounding Tarangire National Park in Tanzania. J. Tour. Cult. Chang. 2018, 16, 248-264. [CrossRef]

7. Morse, S. Developing sustainability indicators and indices. Sustain. Dev. 2015, 23, 84-95. [CrossRef]

8. Bell, S.; Morse, S. Groups and indicators in post-industrial society. Sustain. Dev. 2014, 22, 145-157. [CrossRef]

9. Strezov, V.; Evans, A.; Evans, T.J. Assessment of the Economic, Social and Environmental Dimensions of the Indicators for Sustainable Development. Sustain. Dev. 2016, 25, 242-253. [CrossRef]

10. Steuer, R.; Hametner, M. Objectives and indicators in sustainable development strategies: Similarities and variances across Europe. Sustain. Dev. 2013, 21, 224-241. [CrossRef]

11. Chinowsky, P.; Schweikert, A.; Hayles, C. Potential impact of climate change on municipal buildings in South Africa. Procedia Econ. Financ. 2015, 18, 456-464. [CrossRef]

12. Bavani, A.R.M.; Morid, S. Impact of Climate Change on the Water Resources of Zayandeh Rud Basin. JWSS 2006, 9, 17-28.

13. Moradi, S.; Nozari, H. Zayandehrud Water Crisis Study due to Climate Change. In Proceedings of the National Conference on Solutions to Water Crisis in Iran and the Middle East, water research center, Shiraz, Scientific Conferences Center, Shiraz, Iran, 20 February 2014. (In Persian).

14. Mahmoudi, A.; Soltani, A.; Salimian, R.S.; Jafari, M.M. Isfahan Climate Change Trend. In Proceedings of the Second Iranian National Conference on Ecological Agriculture, Gorgan, Iran, 14-15 October 2007. (In Persian)

15. Rajkovich, N.B.; Okour, Y. Climate Change Resilience Strategies for the Building Sector: Examining Existing Domains of Resilience Utilized by Design Professionals. Sustainability 2019, 11, 2888. [CrossRef]

16. Warner, K.; Zommers, Z.; Wreford, A.; Hurlbert, M.; Viner, D.; Scantlan, J.; Tamang, C. Characteristics of Transformational Adaptation in Climate-Land-Society Interactions. Sustainability 2019, 11, 356. [CrossRef]

17. Shaban, A. Indicator and Aspects of Hydrogical Drought in Lebanon; Springer Science+Business Media: Berlin, Germany; B. V. Water Resource Management: Berlin, Germany, 2009; Volume 23, pp. 1875-1891.

18. Tabari, H.; Nikbakht, J.; Talaee, P.H. Hydrological drought assessment in Northwestern Iran based on streamflow drought index (SDI). Water Resour. Manag. 2013, 27, 137-151. [CrossRef]

19. Zhao, L.; Lyu, A.; Wu, J.; Hayes, M.; Tang, Z.; He, B.; Liu, M. Impact of meteorological drought on streamflow drought in Jinghe River Basin of China. Chin. Geogr. Sci. 2014, 24, 694-705. [CrossRef]

20. Belhassan, K. Relationship between River Flow, Rainfall and Groundwater pumpage in Mikkes Basin (Morocco). Iran. J. Earth Sci. 2011, 3, 98-107.

21. Noohar, A.; Qashqaizadeh, N.; Heydarzadeh, M.; Aydoun, M.R.; Panahi, M. Evaluation of Drought and its Impact on Surface and Groundwater Resources. Earth Sci. Res. 2016, 7, 4-28.

22. Seyyedipour, M.; Ghasemi, M.; Heydarpour, G.; Zareian, J. The Influence of Zayandehrood River Surface Flow on Groundwater Fluctuations of Near Aquifers. In Proceedings of the Second Iranian National Hydrology Conference, Shahrekord University, Shahrekord, Iran, 11-12 July 2017. (In Persian). 
23. Mirasi, S.; Rahnama, H.; Binesh, S.M.; Eliasi, M. Geotechnical Investigation of Groundwater Subsidence by Groundwater Harvesting and Indeterminate Development. In Proceedings of the First National Conference on Civil and Development, Islamic Azad University of Rasht, Rasht, Iran, 23-24 February 2011.

24. Esteban, D.V.; Pedro, R.M.; Tomás, R. Multitechnical approach for damage assessment and reinforcement of buildings located on subsiding areas: Study case of a 7-story RC building in Murcia (SE Spain). Eng. Struct. 2018, 173. [CrossRef]

25. Van Loon, A.F. Hydrological drought explained. Wiley Interdiscip. Rev. Water 2015, 2, 359-392. [CrossRef]

26. Toll, D.G.; Abedin, Z.; Buma, J.; Cui, Y.; Osman, A.S.; Phoon, K.K. The Impact of Changes in the Water Table and Soil Moisture on Structural Stability of Buildings and Foundation Systems: Systematic Review; Durham University: Durham, UK, 2012.

27. Seyedghasemi, S.; Abrishamchi, A.; Tajrishi, M. Assessment of Climate Change Changes in Zayandehrood River. In Proceedings of the Second Conference on Water Resources Management, Isfahan University of Technology, Iranian Association of Water Resources Science and Engineering, Isfahan, Iran, 22-23 January 2006. (In Persian).

28. Galluccio, M.C.; Abbafati, M. Drought Assesment and Forecasting. Meteorol. Organ. Weather Clim. Water 2005, 8-9.

29. Maleki, R.; Ahmadpour, S.M. Estimating Domestic Tourism Demand Function in Isfahan with Emphasis on Zayandehrood Drought. In Proceedings of the International Conference on Urban Economics, Iranian Association of Urban Economics, Tehran, Iran, 18 May 2016. (In Persian).

30. Ostad-Ali-Askari, K.; Shayannejad, M.; Ghorbanizadeh-Kharazi, H. Artificial neural network for modeling nitrate pollution of groundwater in marginal area of Zayandeh-rood River, Isfahan, Iran. KSCE J. Civil Eng. 2017, 21.1, 134-140. [CrossRef]

31. Ali Dosti, N. Investigating Factors Affecting Zayandehrood Land and its Impact on Isfahan Occupations. In Proceedings of the First Iranian National Environmental Conference, Payam Noor University of Dehaghan, Dehaghan, Iran, 22 May 2014. (In Persian).

32. Shahnoshi, M.; Jalalian, J.; Atai, H. Drought production crisis due to drought in Zayandehrood catchment of Isfahan and Gavkhuni lagoon. In Proceedings of the Second International Conference on Research in Science and Technology, Karine Institute of Excellence, Istanbul, Turkey, 14 March 2015. (In Persian).

33. Antronico, L.; Coscarelli, R.; De Pascale, F.; Condino, F. Social Perception of Geo-Hydrological Risk in the Context of Urban Disaster Risk Reduction: A Comparison between Experts and Population in an Area of Southern Italy. Sustainability 2019, 11, 2061. [CrossRef]

34. Halimi, B.Z.M. The Impact of Climate Change on Power Consumption in Iran's Household Sector. Master's Thesis, Faculty of Humanities, Tarbiat Modarres University, Tehran, Iran, 2011. (In Persian).

35. Camilleri, M.; Jaques, R.; Isaacs, N. Impacts of climate change on building performance in New Zealand. Build. Res. Inf. 2001, 29, 440-450. [CrossRef]

36. Sarvari, H.; Valipour, A.; Yahya, N.; Noor, N.; Beer, M.; Banaitiene, N. Approaches to Risk Identification in Public-Private Partnership Projects: Malaysian Private Partners' Overview. Adm. Sci. 2019, 9, 17. [CrossRef]

37. Rakhshanifar, M.; Hosseini, M.; Abdullah, A. Safety and Health in Refurbishment Works Including Partial Demolition. In Applied Mechanics and Materials; Trans Tech Publications: Stafa-Zurich, Switzerland, 2015; Volume 735, pp. 99-103.

38. Valipour, A.; Sarvari, H.; Tamošaitiene, J. Risk Assessment in PPP Projects by Applying Different MCDM Methods and Comparative Results Analysis. Adm. Sci. 2018, 8, 80. [CrossRef]

39. Chan, J.K.; Xing, G.H.; Xu, Y.; Liang, Y.; Chen, L.X.; Wu, S.C.; Wong, M.H. Body loadings and health risk assessment of polychlorinated dibenzo-p-dioxins and dibenzofurans at an intensive electronic waste recycling site in China. Environ. Sci. Technol. 2007, 41, 7668-7674. [CrossRef]

40. Connelly, A.; Carter, J.; Handley, J.; Hincks, S. Enhancing the practical utility of risk assessments in climate change adaptation. Sustainability 2018, 10, 1399. [CrossRef]

41. Thomas, S.; Luis, V. The Analytic Network Process. In Decision Making with the Analytic Network Process. Economic, Political, Social and Technological Applications with Benefits, Opportunities, Costs and Risks; Springer: Berlin, Germany, 2006; pp. 1-26. [CrossRef]

42. Valipour, A.R.; Sarvari, H.; Noor, N.M.; Rashid, A.S.A. Analytic network process (ANP) to risk assessment of gas refinery EPC projects in Iran. J. Appl. Sci. Res. 2013, 9, 1359-1365. 
43. Casagrande, J.; Pike, M.; Smith, P. An Improved Approximate Formula for Calculating Sample Sizes for Comparing Two Binomial Distributions. Biometrics 1978, 34, 483-486. [CrossRef]

44. Woolson, R.F.; Bean, J.A.; Rojas, P.B. Sample Size for Case-Control Studies Using Cochran's Statistic. Biometrics 1986, 42, 927. [CrossRef]

45. İhsan, Y.; Metin, D. Using the analytic network process (ANP) in a SWOT analysis. Inf. Sci. 2007, 177, 3364-3382. [CrossRef]

46. Saaty, L.T.; Tran, L.T. On the invalidity of fuzzifying numerical judgments in the Analytic Hierarchy Process. Math. Comput. Model. 2007, 46, 962-975. [CrossRef]

47. Dano, U.L.; Balogun, A.-L.; Matori, A.-N.; Wan Yusouf, K.; Abubakar, I.R.; Said Mohamed, M.A.; Aina, Y.A.; Pradhan, B. Flood Susceptibility Mapping Using GIS-Based Analytic Network Process: A Case Study of Perlis, Malaysia. Water 2019, 11, 615. [CrossRef]

48. Lyu, H.-M.; Wu, Y.-X.; Shen, J.S.; Zhou, A.-N. Assessment of Social-Economic Risk of Chinese Dual Land Use System Using Fuzzy AHP. Sustainability 2018, 10, 2451. [CrossRef]

49. Yu, K.; Zhou, L.; Hu, C.; Wang, L.; Jin, W. Analysis of Influencing Factors of Occupational Safety and Health in Coal Chemical Enterprises Based on the Analytic Network Process and System Dynamics. Processes 2019, 7, 53. [CrossRef]

50. Zavadskas, E.K.; Antucheviciene, J.; Vilutiene, T.; Adeli, H. Sustainable Decision-Making in Civil Engineering, Construction and Building Technology. Sustainability 2018, 10, 14. [CrossRef]

51. World Meterological Organization. Implementation of Drought Early-warning System over IRAN (DESIR)| GFCS. Available online: https://gfcs.wmo.int/DESIR (accessed on 27 October 2019).

52. Assari, A.; Assari, E. Urban spirit and heritage conservation problems: Case study Isfahan city in Iran. J. Am. Sci. 2012, 8, 203-209, Retrieved 7 January 2013.

53. Allahdadian, L.; Khoshakhlagh, R. Economic Water Reallocation in the Zayande Rood Basin (Iran) Among Different Uses via Designed Software. Int. J. Acad. Res. Econ. Manag. Sci. 2013, 2, 2226-3624. [CrossRef]

54. Fuertes, A.; Casals, M.; Gangolells, M.; Forcada, N.; Macarulla, M.; Roca, X. An Environmental Impact Causal Model for improving the environmental performance of construction processes. J. Clean. Prod. 2013, 52, 425-437. [CrossRef]

55. Sun, M.; Meng, X. Taxonomy for change causes and effects in construction projects. Int. J. Proj. Manag. 2009, 27, 560-572. [CrossRef]

56. Juan, Y.K.; Perng, Y.H.; Castro-Lacouture, D.; Lu, K.S. Housing refurbishment contractors selection based on a hybrid fuzzy-QFD approach. Autom. Constr. 2009, 18, 139-144. [CrossRef]

57. Mohammadi, F.; Nateghi, F.; Pourhejazi, S.P.; Abdullah, A.; Gandomi, N.; Sadi, M.K. Part deployment model using combined quality function deployment and cybernetic fuzzy analytic network process. Indian J. Sci. Technol. 2014, 7, 53-62.

(C) 2019 by the authors. Licensee MDPI, Basel, Switzerland. This article is an open access article distributed under the terms and conditions of the Creative Commons Attribution (CC BY) license (http://creativecommons.org/licenses/by/4.0/). 